\title{
35. NOTE ON THE OCCURRENCE OF NATIVE COPPER IN TERTIARY NANNOFOSSIL OOZES FROM THE GOBAN SPUR (HOLE 550) ${ }^{1}$
}

\author{
Robert W. O’B. Knox, Institute of Geological Sciences, Leeds ${ }^{2}$
}

In the course of examining the Tertiary cores from Hole 550 for volcanic ash layers, we observed minor amounts of a bright blue green mineral at three horizons (Fig. 1). When separated from the enclosing sediment, the blue green material proved to be coating a dark brown core of metallic copper.

In two of the occurrences the copper is associated with carbonate ooze host sediment: nannofossil ooze in Sample 550-29-2, 66.5-67.5 $\mathrm{cm}$ and somewhat coarser grained turbiditic siltstone laminae in Sample 550-29-4, $138-140 \mathrm{~cm}$. In the latter sample, the copper is clearly acting as a cementing agent for quartz silt and foraminiferal grains. In the third occurrence (Sample 550-36-2, $41-43 \mathrm{~cm}$ ), the copper lies along fractures within a soft chert concretion, indicating that the copper is again of secondary origin and proving that its precipitation followed the formation of the concretionary silica.

Detailed chemical analysis has not been carried out on the copper, but an electron-microprobe analysis of one particle indicated that the copper was almost pure; the only other elements detected were trace amounts of $\mathrm{Si}$ and $\mathrm{Al}$, indicating slight contamination by detrital impurities.

Native copper has previously been reported from several other DSDP sites. In some the copper is associated with the basaltic basement (Site 282: Ovenshine et al., 1975, p. 1100; Site 553: Shipboard Scientific Party, in press), whereas in others it is associated with sediments (Site 105: Shipboard Scientific Party, 1972, p. 267 and Zemmels et al., 1972, p. 786; Site 364: Siesser, 1979; Site 553: Shipboard Scientific Party, in press). The sedimentary occurrences are similar to those in Hole 550, with the copper occurring in association with a green coating material (termed palagonite in the Site 105 accounts) and displaying both intergranular cement habits (Site 364) and vein habits (Site 105).

The possible mechanisms of copper concentration and precipitation in deep sea sediments have been reviewed by Siesser (1979). They include (1) direct hydrothermal precipitation, (2) diagenetic precipitation following the concentration of copper in seawater as a result of submarine exhalations, and (3) diagenetic precipitation following the concentration of copper in organic tests.

\footnotetext{
${ }^{1}$ Graciansky, P. C. de, Poag, C. W., et al., Init. Repts. DSDP, 80: Washington (U.S. Govt. Printing Office). This paper is published with the approval of the Director, British Geological Survey (N.E.R.C.).

2 Address: Institute of Geological Sciences, British Geological Survey, Ring Road Halton, Leeds LS15 8TQ, United Kingdom (present address: British Geological Survey, Keyworth, Nottingham NG12 5GG, United Kingdom).
}

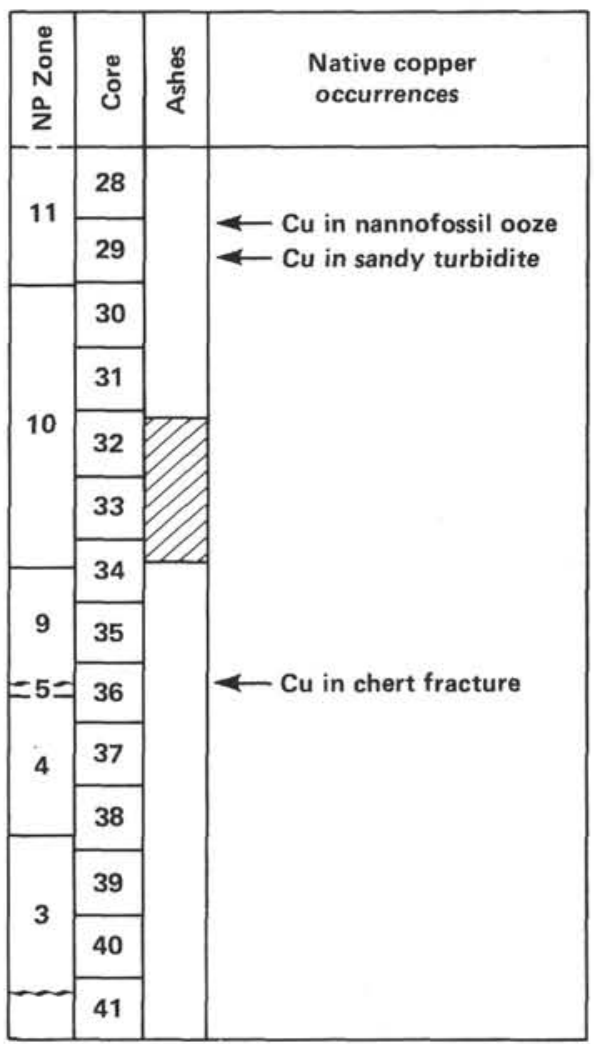

Figure 1. Distribution of native copper samples in the early Paleogene sequence of Hole 550. Hatching indicates zone of interbedded bentonites.

In Hole 550, there is no evidence of direct hydrothermal precipitation. The copper seems to be associated with well-preserved nannofossil oozes with no signs of recrystallization or precipitation of other minerals. The possibility that the copper originated from submarine exhalations is more difficult to assess. It is unlikely that such processes took place in the immediate vicinity of the Goban Spur sites, but the possibility that copper-bearing solutions were released from basaltic eruptions in (for example) the Rockall area cannot be ruled out.

Whatever the ultimate source of the copper, it seems most likely that its concentration and precipitation in the sediments of Hole 550 did not take place as the direct result of volcanic or hydrothermal activity. In view of the essentially biogenic composition of the host sediments, it is most probable that the copper was introduced into the sediment through the accumulation of the remains of microplankton, some of which are known to concen- 
trate copper and other metallic elements (Nicholls et al., 1959). Precisely how such biogenically fixed copper would be subsequently mobilized and reprecipitated is beyond the scope of this chapter, although low Eh and probably also low sulfide ion concentrations would seem to be essential factors.

If, as seems to be the case, the occurrence of native copper in the sediments is not directly related to volcanic or hydrothermal activity, but rather to the diagenetic redistribution of originally disseminated copper, it is possible that the occurrences noted in the basaltic basement are of similar origin. However, copper has been observed down to $80 \mathrm{~m}$ below the basalt surface (Site 553, Shipboard Scientific Party, in press), and it is doubtful that interstitial water from the overlying sediments would have penetrated to such depths. It seems more probable that the copper was precipitated during the crystallization of the lavas, as suggested by Jensen (1982) for native copper in the Tertiary basalts of the Faeroe Islands.

\section{REFERENCES}

Jensen, A., 1982. The distribution of $\mathrm{Cu}$ across three basaltic lava flows from the Faroe Islands. Bull. Geol. Soc. Denmark, 31:1-10.

Nicholls, G. D., Curl, H., and Bowen, V. T., 1959. Spectrographic analyses of marine plankton. Limnol. Oceanogr., 4:472-478.

Ovenshine, A. T., Winkler, G. R., Andrews, P. B., and Gostin, V. A., 1975. Chemical analyses and minor element composition of Leg 29 basalts. In Kennett, J. P., Houtz, R. E., et al., Init. Repts. DSDP, 29: Washington (U.S. Govt. Printing Office), 1097-1102.

Shipboard Scientific Party, 1972. Site 105-lower continental rise hills. In Hollister, C. D., Ewing, J. I., et al., Init. Repts. DSDP, 11: Washington (U.S. Govt. Printing Office), 219-312. in press. Site 553. In Roberts, D. G., Schnitker, D., et al., Init. Repts. DSDP, 81: Washington (U.S. Govt. Printing Office). Siesser, W. G., 1979. Native copper in DSDP Leg 40 sediments. In Bolli, H. M., Ryan, W. B. F., et al., Init. Repts. DSDP, Suppl. to Vols. 38, 39, 40, and 41: Washington (U.S. Govt. Printing Office), 761-765.

Zemmels, I., Cook, H. E., and Hathaway, J. C., 1972. X-ray mineralogy studies-Leg 11. In Hollister, C. D., Ewing, J. I., et al., Init. Repts. DSDP, 11: Washington (U.S. Govt. Printing Office), 729-789.

Date of Initial Receipt: March 22, 1983

Date of Acceptance: July 8, 1983 